\title{
Pengaruh Media Video terhadap Motivasi Belajar dan Hasil Belajar Kognitif Pembelajaran IPA Kelas V Sekolah Dasar
}

\author{
Corry Febriani \\ Universitas Palangka Raya. Jalan Yos Sudarso, Palangka, Jekan Raya, Kota Palangka Raya, \\ Kalimantan Tengah 74874, Indonesia \\ Korespondensi Penulis. Email: corycici7@gmail.com \\ Received: 14 April 2016; Revised:13 June 2016; Accepted: 3 January 2017
}

\begin{abstract}
Abstrak
Penelitian ini bertujuan untuk mengetahui: (1) pengaruh media video terhadap motivasi belajar peserta didik pada pembelajaran IPA, (2) pengaruh media video terhadap hasil belajar kognitif peserta didik pada pembelajaran IPA, (3) pengaruh media video terhadap motivasi belajar dan hasil belajar kognitif peserts didik pada pembelajaran IPA. Penelitian ini adalah quasi experiment. .Populasi penelitian ini adalah peserta didik kelas V se gugus 04 Palangka Raya. Sampel penelitian ditentukan dengan teknik cluster random sampling. Pengumpulan data menggunakan skala motivasi dan tes. Pengujian hipotesis dengan teknik MANOVA. Penelitian ini membuktikan bahwa terdapat pengaruh positif pada pembelajaran IPA yang menggunakan media video dibandingkan dengan pembelajaran IPA yang menggunakan media gambar terhadap motivasi belajar dan hasil belajar kognitif pembelajaran IPA.
\end{abstract}

Kata Kunci: media video, motivasi belajar, hasil belajar kognitif

\section{The Effect of Video Media on Learning Motivation and Cognitif Learning Outcomes in Natural Science Subject of the Fifth Grade Students of Elementary Schools}

\begin{abstract}
This research aims to describe: (1) the effects of the video media on students' learning motivation related to the natural science subject; (2) the effects of the video media on students' cognitive learning outcomes related to the natural science subject; (3) the effects of the video media on students' learning motivation and cognitive learning outcomes related to the natural science subject. This research is a quasi-experiment. The population was the students of Fifth Grade Students of Elementary Schools Location 04 Palangkaraya. The sample was established using the cluster random sampling technique. The data collection used a motivation scale and test. The hypotesis testing used the MANOVA. The result of the research shows that there there is a positive effect of learning motivation and cognitive learning result in natural science subject of the fifth grade students of elementary schools 04 Palangka Raya before and after using video media.
\end{abstract}

Keywords: video media, learning motivation, cognitive learning result.

How to Cite: Pebriani, C. (2017). Pengaruh penggunaan media video terhadap motivasi dan hasil belajar kognitif pembelajaran IPA kelas V. Jurnal Prima Edukasia, 5(1), 11-21. doi:http://dx.doi.org/10.21831/jpe.v5i1.8461

Permalink/DOI: http://dx.doi.org/10.21831/jpe.v5i1.8461 


\section{Jurnal Prima Edukasia, 5 (1), January 2017 - 12 \\ Corry Febriani}

\section{Pendahuluan}

Pendidikan berperan penting dalam mempersiapkan sumber daya manusia yang berkualitas. Pendidikan sebagai salah satu tempat untuk meningkatkan kualitas sumber daya manusia yang dilaksanakan melalui pembelajaran. Pembelajaran diharapkan mampu memberikan kedewasaan kepada setiap individu. Menurut Jamaris (2013, p. 2) pendidikan merupakan usaha yang dilakukan secara sadar dalam rangka membimbing dan mengarahkan perkembangan anak ke arah dewasa. Sehingga melalui pendidikan mampu mempersiapkan sumber daya manusia yang lebih berkualitas dan mengembangkan setiap individu ke arah pendewasaan.

Perkembangan pendidikan saat ini sudah terkena dampak oleh adanya perkembangan teknologi. Untuk mengimbangi dari dampak teknologi ini diharapkan para pengajar mampu memberikan sebuah pembelajaran yang interaktif, inspiratif, menyenangkan, menantang, memotivasi peserta didik untuk berpartisipasi aktif, serta memberikan ruang yang cukup bagi prakarsa, kreativitas dan kemandirian sesuai bakat, minat dan perkembangan fisik peserta didik serta psikologis peserta didik. Agar peserta didik lebih termotivasi pada saat proses pembelajaran maka dapat diberikan media pembelajaran yang mampu memberikan sebuah pembelajaran yang menarik. Saat ini guru dituntutkan untuk mengajar lebih kreatif dan tidak membosankan. Untuk menciptakan hal tersebut, guru harus pandai berinovasi dalam penggunaan metode yang tepat dalam pembelajaran. Sayangnya, saat ini variasi metode dalam pembelajaran khususnya pada pembelajaran IPA masih jarang dilakukan guru. Selain itu, guru memerlukan media pembelajaran sebagai bagian dari alat bantu mengajar. Sekarang sudah saatnya guru melakukan perubahan yang lebih baik dan mengajak peserta didik berpartisipasi secara aktif untuk dapat berkompetensi, baik secara individu mauapun secara kelompok. Penggunaan media pembelajaran merupakan salah satu cara untuk meningkatkan minat belajar, pemilihan media pun disesuikan dengan kondisi peserta didik dan dekat dengan peserta didik.

Pendidikan di sekolah dasar terdiri atas beberapa mata pelajaran yang harus dipelajari oleh peserta didik. Salah satu mata pelajaran yang turut berperan penting dalam upaya mewujudkan generasi penerus bangsa yang cerdas dalam berpendidikan wawasan, keterampilan dan sikap ilmiah sejak dini bagi anak adalah mata pelajaran Ilmu Pengetahuan Alam (IPA). Mata pelajaran IPA merupakan mata pelajaran yang wajib ditempuh oleh peserta didik di sekolah dasar. Di tingkat SD/MI diharapkan ada penekanan pembelajaran Salingtemas (Sains, lingkungan, teknologi, dan masyarakat) yang diarahkan pada pengalaman belajar untuk merancang dan membuat suatu karya melalui penerapan konsep IPA dan kompetensi bekerja ilmiah secara bijaksana (Badan Standar Nasional Pendidikan, 2006, p. 161). Hal ini menyebabkan pihak sekolah harus senantiasa mengemas pesan pembelajaran dengan efektif agar tujuan pembelajaran dapat tercapai. Pencapaian pembelajaran IPA di sekolah dasar didasarkan pada pemberdayaan peserta didik untuk membanun kemampuan, bekerja ilmiah dan pengetahuan sendiri yang difasilitasi oleh guru.

Pembelajaran IPA dapat membantu kita dalam memahami mengetahui kehidupan makhluk hidup disekitar kita. Buxton dan Provenzo (2007, p. 6) mengartikan IPA merupakan sekumpulan fakta dan pengetahuan untuk menjelaskan tentang alam semesta. Melalui pembelajaran sains dapat mengetahui fakta dan pengetahuan tentang alam semesta. Melalui pembelajaran IPA yang diberikan di sekolah dasar diharapkan menjadi wahana bagi peserta didik untuk mempelajari diri sendiri dan alam sekitar.

Pengertian IPA dalam penelitian adalah pengetahuan tentang gejala alam yang dituangkan berupa fakta, konsep, prinsip dan penemuan yang berkaitan dengan gejala alam yang terjadi disekitar dan memiliki tujuan untuk mengembangkan pengetahuan konsep-konsep IPA yang bermanfaat dan dapat diterapkan dalam kehidupan peserta didik sehari-hari serta dapat menanamkan rasa ingin tahu dan sikap positif terhadap pembelajaran IPA.

Ketika proses pembelajaran berlangsung seorang guru harus mempelajari terlebih dahulu karakteristik yang dimiliki oleh peserta didiknya agar pembelajaran dapat dengan mudah dipahami oleh peserta didi, karena dengan mengetahui karakteristiknya guru mampu menyiapkan cara yang tepat dalam menghadapi peserta didiknya. Adapun karakteristik peserta didik kelas $\mathrm{V}$ yang berada pada kisaran usia 1012 tahun seperti yang dikemukakan oleh Piaget dalam Muijs dan Reynolds (2008, p. 25) yakni bahwa pada usia tersebut peserta didik telah 


\section{Jurnal Prima Edukasia, 5 (1), January 2017 - 13}

Corry Febriani

memulai pemikiran berlogika serta dapat mengadopsi sudut pandang orang lain. Pada tahap perkembangan ini anak berpikir secara operasional dengan penalaran logis dalam situasi konkret dan kemampuan mengklasifikasi (menggolong-golongkan) sudah ada tetapi belum dapat memahami masalah-masalah yang bersifat abstrak. Pada masa ini pemikiran anak masih terbatas hanya ada pada apa yang mereka alami melalui suatu pengalaman langsung. Oleh karena itu, pada masa ini guru dalam proses pembelajaran perlu membuat atau merancang kemampuan yang dimiliki anak sehingga nantinya mampu berkembang secara optimal. Sehingga guru dituntut untuk mampu memilih media pembelajaran yang tepat sebagai alat antu dalam menyampaikan materi pembelajaran.

Pada keterbatasan ini, jika dalam mempelajari materi-materi IPA yang masih bersifat abstrak dan tidak disertakan dengan hal-hal yang dapat membantu peserta dalam memahami materi, maka hasil yang akan dicapai oleh pesrta didik dalam pembelajaran IPA berupa hafalan materi saja. Dapat dikatakan bahwa pada cara berpikir operasional konkret peserta didik mengalami kekurangan, karena masih mempelajari hal yang masih bersifat abstrak tanpa ada alat penunjang yang dapat membantu memahami pembelajaran IPA. Hendaknya dalam sebuah pembelajaran IPA agar dapat menjadi lebih bermakna pembelajaran dapat dilakukan dengan bantuan sebuah media pembelajaran, agar peserta didik lebih termotivasi dan bersemangat untuk mengikuti proses pembelajaran. Pada keadaan seperti inilah dapat diupayakan dengan pemberian suatu media pembelajaran yang dapat membangkitkan semangat peserta didik untuk belajar. Indaryati dan Jailani (2015, p. 85) mengatakan bahwa media pembelajaran adalah salah satu faktor utama yang dapat mempengaruhi hasil belajar siswa, karena melalui medialah pesan pembelajaran dapat disampaikan sesuai dengan tujuan pembelajaran tersebut.

Berdasarkan kenyataannya di lapangan ada hal-hal yang tidak seperti yang diharapkan berdasarkan hasil observasi dan wawancara yang dilakukan peneliti dengan guru-guru di SD se gugus 04 Palangka Raya. Pada sekolah tersebut didapatkan hasil sebagai berikut: hasil observasi yang dilakukan peneliti pada tanggal 9-21 Maret 2015 didapatkan empat hal, yaitu pertama banyak terdapat peserta didik yang tidak aktif dalam kegiatan belajar mengajar dan hanya sibuk bermain sendiri, saling berbicara dengan temannya satu sama lain dan menggangu temannya tanpa memperhatikan penjelasan dari guru dan itu dilakukan pada saat pembelajaran IPA. Kedua proses pembelajaran masih menggunakan metode ceramah dan tanya jawab hal ini cenderung menempatkan guru sebagai pusat (teacher-centered learning). Ketiga belum memanfaatkan media yang tepat dan efektif dalam pembelajaran IPA padahal alatalat penunjangnya sudah tersedia seperti laptop dan LCD. Keempat hasil belajar peserta didik yang kurang optimal pada pembelajaran IPA hal ini dinyatakan dengan rata-rata nilai UTS semester 2 kelas V SD Se Gugus 04 Palangka Raya untuk mata pelajaran IPA adalah 65 belum mencapai KKM 80.

Keberhasilan suatu proses pembelajaran tidak dapat terlepas dari media pembelajaran sebgai alat penunjang penyampaian informasi. Peserta didik yang masih dalam tahap operasional konkret memerlukan pembelajaran yang dapat membuat mereka mengingat dengan jelas pembelajaran yang sudah diajarkan, melalui media ini guru dapat memberikan sebuah inovasi baru dalam proses pembelajaran. Kustandi dan Sutjipto (2013, p. 8) media pembelajaran merupakan alat yang dapat membantu proses belajar mengajar dan berfungsi untuk memperjelas makna pesan yang disampaikan, sehingga dapat mencapai tujuan pembelajaran dengan lebih baik dan sempurna. Melalui media pembelajaran ini tujuan pembelajaran akan tercapai dengan baik dan sempurna. Penggunaan media media pembelajaran dapat disesuaikan dengan materi pembelajaran agar dapat tercapainya tujuan pembelajaran. Rusman (2013, p. 173) membagi jenis media menjadi media audio, media visual dan media audiovisual. Setiap jenis media memiliki karak-teristiknya dan manfaatnya masing-masing, pada penelitian ini menggunakan jenis media audiovisual yaitu berupa video. Media video dapat digunakan untuk menyampaikan infor-masi yang dapat didengar dan dapat dilihat oleh peserta didik sehingga peserta didik dapat mendeskripsikan suatu masalah, konsep, suatu yang bersifat abstrak dan tidak lengkap menjadi jelas dan lengkap.

Media pembelajaran yang dikemas dalam bentuk video dapat memberikan memori jangka panjang kepada peserta didik karena media video disajikan melalui animasi, gambar, dan suara. Media video memiliki potensi untuk lebih disukai peserta didik, hal ini dikarenakan 


\section{Jurnal Prima Edukasia, 5 (1), January 2017 - 14}

Corry Febriani

melalui media video peserta didik dapat menyaksikan dan membayangkan apa yang disajikan pada saat pemutaran video berlangsung. Manning dan Johnson (2011, p. 119) video dapat digunakan untuk medorong kemajuan pendidikan melalui gabungan dari efek visual, dialog, demonstrasi dan yang paling baru adanya interaksi penampilan. Sehingga dengan adanya video dalam pembelajaran dapat membuat peserta didik dengan mudah memahami tujuan pembelajaran yang ingin dicapai. Maka wajar jika peserta didik yang diajar dengan bantuan media video memiliki semangat dan gairah pada saat proses pembelajaran.

Menurut Michael, McClendon dan Branch (2009, p. 214) menyebutkan bahwa video adalah untuk berkomunikasi pesan yang lebih kuat menginspirasi, menegaskan, meningkatkan, dan membujuk, jika dibandingkan dengan informasi yang sama dalam format tekstual sendiri. Penggunaan video lebih baik dalam menyampaikan informasi karena hanya dengan video dapat mencakup semua kebutuhan yang diperlukan dalam memperoleh informasi. Pembelajaran dengan media video dapat membuat pembelajaran menjadi menyenangkan serta dapat meningkatkan motvasi dan hasil belajar peserta didik. Media video juga mampu mendorong munculnya ide-ide kreatif dari peserta didik dengan adanya visualisai berupa gambar bergerak dan suara yang disajikan melalui media video.

Jadi media video adalah media pembelajaran yang dapat mengkomuikasikan pesan pembelajaran lebih kuat, tegas, meninspirasi, meningkatkan dan membujuk peserta didik dalam belajar serta dapat membangkitkan kegembiraan dalam proses belajar dan dapat meningkatkan hasil belajar peserta didik yang disajikan dengan audio visual agar pembelajaran dapat dengan mudah diterima oleh peserta didik. Melalui media video materi pembelajaran yang akan disampaikan mampu membangkitkan semangat peserta didik untuk belajar karena materi yang dipelajari dapat dengan mudah dimengerti dan dipahami peserta didik melalui gambar, suara dan animasi yang disajikan, sehingga dapat meningkatkan motivasi belajar dan hasil belajar peserta didik.

Jika melakukan pembelajaran dengan motivasi yang besar maka akan memperoleh hasil belajar yang maksimal juga. Motivasi merupakan salah satu faktor yang mempengaruhi peserta didik dalam belajar. Schunk, Pintrich dan Meece. (2010, p. 5) mengatakan bahwa motivasi memiliki hubungan dengan kemampuan belajar. Motivasi sangat mempengaruhi belajar peserta didik. Jamaris (2013, p. 170) mengatakan bahwa motivasi adalah suatu kekuatan atau tenaga yang membuat individu bergerak dan memilih untuk melakukan sesuatu kegiatan dan mengarahkan kegiatan tersebut ke arah tujuan yang akan dicapainya. Seseorang akan mencapai tujuan yang diinginkannya apabila seseorang itu mempunyai motivasi yang kuat dalam dirinya. Sehingga pada proses pembelajaran dengan adanya motivasi belajar dapat menghasilkan suatu keinginan untuk berhasil, dorongan dan kebutuhan dalam belajar dan antusias dalam belajar pada diri peserta didik. Inilah sebabnya motivasi sangat berpengaruh pada saat proses pembelajaran karena melalui motivasi peserta didik mampu mencapai tujuan yang ingin dicapainya. Setiap peserta didik memiliki motivasi yang berbeda-beda dalam hal belajar, jadi tugas seorang guru adalah harus mampu membangkitkan motivasi belajar peserta didik agar bersemangat dalam mengikuti proses pembelajaran.

Motivasi dalam diri individu diklasifikasikan menjadi dua, yaitu motivasi intrinsik dan motivasi ekstrinsik. Brophy (2010, p. 7) mengatakan bahwa motivasi intrinsik adalah seseorang yang mengejar keinginan sendiri karena mereka ingin bukan karena mereka perlu. Sedangkan motivasi ekstrinsik adalah seseorang yang mengejar keinginannya karena ada kebutuhan yang dingini. Motivasi intrinsik adalah motivasi belajar yang merupakan dorongan dari dalam diri seseorang. Motivasi belajar ini berasal dari hati peserta didik tersebut dalam menyelesaikan tugasnya tanpa ada paksaan untuk beroleh reward, hadiah atau hukuman. Motivasi intrsinsik timbul tanpa ada pengaruh dari luar. Sementara Motivasi belajar ekstrinsik adalah motivasi yang terdorong dari luar diri seseorang yang timbul dari dorongan dan kebutuhan seseorang tidak secara mutlak berhubungan dengan kegiatan belajarnya sendiri. Motivasi belajar ini berasal dari dorongan luar diri peserta didik dalam menyelesaikan tugasnya karena terpengaruh oleh reward, hadiah dan hukuman.

Kegiatan pembelajaran yang dilakukan guru harus mampu mendorong peserta didik menjadi aktif pada saat proses pembelajaran berlangsung, sehingga tujuan pembelajaran dapat tercapai. Sehingga proses pembelajaran dapat dilakukan melalui pembelajaran yang menyenangkan dan dapat memotivasi peserta 


\section{Jurnal Prima Edukasia, 5 (1), January 2017 - 15}

Corry Febriani

didik agar lebih giat lagi dalam belajar. Proses yang menyenangkan tersebut dapat memudahkan peserta didik dalam meningkatkan motivasi belajarnya sehingga akan berdampak juga pada peningkatan hasil belajar kognitifnya.

Setiap proses pembelajaran selalu menghasilkan hasil belajar. Hasil belajar merupakan bagian terpenting dalam pembelajaran. Hasil belajar kognitif merupakan salah satu acuan dalam mencapai tujuan pendidikan. Kemampuan intelektual peserta didik sangat menentukan keberhasilan dalam memperoleh hasil belajar yang peserta didik inginkan. Banyak hal yang dapat diukur melalui hasil belajar peserta didik. Jihad dan Haris (2008, p. 14) berpendapat bahwa hasil belajar merupakan pencapaian bentuk perubahan perilaku yang cenderung menetap dari ranah kognitif, afektif, dan psikomotorik dari proses belajar yang dilakukan dalam waktu tertentu. Hasil belajar peserta didik dapat dipergunakan sebagai tolak ukur keberhasilan guru dalam mengajar, sehingga guru dapat memperbaiki atau mengulangi bagian dari materi pelajaran yang kurang atau belum dimengerti oleh peserta didik.

Menurut Yamin dan Maisah (2009, p. 76) kemampuan kognitif merupakan kecakapan siswa yang berkaitan dengan kemampuan berpikir; kemampuan memperoleh pengetahuan; kemampuan yang berkaitan dengan pemerolehan pengetahuan pengenalan, pemahaman, dan konseptualisasi, penentuan, dan penalaran. Hasil belajar merupakan hasil dari kegiatan yang telah dikerjakan oleh peserta didik.

Media pembelajaran merupakan salah satu faktor utama yang dapat mempengaruhi hasil belajar peserta didik, karena melalui medialah pesan pembelajaran dapat disampaikan sesuai dengan tujuan pembelajaran tersebut. Untuk mewujudkan efektivitas dalam pembelajaran maka harus memperhatikan bagaimana pesan pembelajaran tersebut dirancang agar peserta didik merasa tertarik untuk mengikuti proses pembelajaran.

Dari beberapa uraian tersebut dapat diambil kesimpulan bahwa hasil belajar kognitif adalah hasil dari usaha belajar peserta didik yang sudah dicapai oleh peserta didik yang mencakup ranah kognitif atau pengetahuan setelah mengerjakan sesuatu yang dipelajarinya dalam kegiatan proses belajar. Hasil belajar kognitif dapat dijadikan sebagai salah satu indikator keberhasilan dalam proses belajar mengajar yang didapatkan dari hasil evaluasi yang dilakukan selama atau setelah kegiatan pembelajaran berlangsung dan dilakukan secara berkesinambungan oleh guru.

Pembelajaran yang jika hanya diberikan tanpa ada inovasi-inovasi pada saat memberikan materi maka akan menyebabkan pesera didik bosan pada saat proses pembelajaran. Jika masih dibiarkan akan berimbas pada rendahnya motivasi belajar dan hasil belajar kogntif peserta didik sehingga mengakibatkan Kriteria Ketuntasan Minimal (KKM) peserta didik tidak mencapai target yang telah ditetapkan.

Permasalahan yang telah diuraikan sebelumnya memerlukan solusi demi perbaikan kualitas pembelajaran IPA. Berdasarkan permasalahan tersebut penulis terdorong untuk melakukan eksperimen tentang pengaruh penggunaan media video terhadap motivasi dan hasil belajar kognitif pembelajaran IPA peserta didik kelas v Palangka Raya.

\section{Metode}

Jenis penelitian ini adalah quasi experiment (eksperimen semu) yang dimaksudkan untuk melihat akibat dari suatu perlakuan. Penelitian ini dikatakan eksperimen semu karena peneliti tidak mengontrol semua variabelvariabel luar yang mempengaruhi pelaksanaan eksperimen.

Penelitian dilaksanakan di SD Se Gugus 04 Palangka Raya yang terdiri atas 8 sekolah, pada semester genap tahun ajaran 2014/2015 pada bulan Mei - Juni 2015. Populasi dalam penelitian ini adalah seluruh peserta didik kelas V di SD Se Gugus 04 Palanka Raya dengan jumlah 280 peserta didik. Sampel yang diambil adalah peserta didik kelas V SD 1 Menteng, SD 8 Menteng dan 6 Menteng, Palangka Raya. Pengambilan sampel ditentukan dengan teknik cluster random sampling. Sehingga diperoleh sampel berjumlah 84 peserta didik.

Variabel bebas dalam penelitian ini adalah media video. Variabel terikat dalam penelitian ini adalah motivasi belajar dan hasil belajar kognitif peserta didik pembelajaran IPA

Instrumen yang digunakan untuk menilai motivasi belajar IPA peserta didik berupa lembar skala motivasi dengan 4 pilihan jawaban. Instrumen pada hasil belajar kogitif IPA peserta didik menggunakan tes.

Validitas instrumen dalam penelitian ini yang ditentukan utamanya atas dasar pertimbangan (judgment) dari para ahli. Validitas instrument diukur dengan reliabilitas instrumen dengan Cronbach's Aplha. 


\section{Jurnal Prima Edukasia, 5 (1), January 2017 - 16 \\ Corry Febriani}

Teknik Analisis Data

\section{Deskripsi Data}

Tahap deskripsi data meliputi membuat tabulasi data untuk setiap variabel, mengurutkan data secara interval dan menyusunnya dalam bentuk tabel distribusi frekuensi, mencari median, rata-rata (mean), dan simpangan baku.

\section{Uji Prasyarat Analisis}

Uji prasyarat analisis dalam penelitian ini menggunakan uji normalitas dengan uji Kolmogorof Smirnov $(K-S)$ dan uji homogenitas dilakukan sebanyak dua kali untuk mengetahui homogenitas univariat dan multivariat. Pengujian homoenitas univariate dilakukan dengan menggunanakn Levene, sedangkan untuk multivariat dilakukan denan menggunakan Box's M.

\section{Hasil dan Pembahasan}

Hasil Analisis Motivasi Belajar

Berdasarkan hasil analisis data statistik deskriptif, seperti yang ditunjukkan pada Tabel 1 maka hasil tes tertinggi yang dicapai oleh peserta didik saat pretest pada kelompok eksperimen 1 adalah 61, kelompok eksperimen 2 adalah 69 dan kelompok kontrol adalah 55 . Hasil terendah kelompok eksperimen 1 adalah 43, kelompok eksperimen 2 adalah 40 dan kelompok kontrol adalah 38 . Hasil posttest tertinggi yang dicapai kelompok eksperimen 1 ada- lah 73, kelompok eksperimen 2 adalah 75, dan kelompok kontrol adalah 68. Hasil posttest terendah kelompok eksperimen 1 adalah 63, kelompok eksperimen 2 adalah 66, dan kelompok kontrol adalah 55 .

\section{Hasil Belajar Kognitif Peserta Didik}

Berdasarkan hasil analisis data statistik deskriptif, seperti yang ditunjukkan pada tabel 2 maka hasil tes tertinggi yang dicapai oleh peserta didik saat pretest pada kelompok eksperimen 1 adalah 20, kelompok eksperimen 2 adalah 21 dan kelompok kontrol adalah 18. Hasil terendah kelompok eksperimen 1 adalah 9, kelompok eksperimen 2 adalah 8 dan kelompok kontrol adalah 9. Hasil posttest tertinggi yang dicapai kelompok eksperimen1 adalah 24, kelompok eksperimen 2 adalah 24, dan kelompok kontrol adalah 21. Hasil posttest terendah kelompok eksperimen 1 adalah 19, kelompok eksperimen 2 adalah 18, dan kelompok kontrol adalah 16.

\section{Uji Normalitas}

Uji normalitas dalam penelitian ini menggunakan uji Kolmogorof Smirnov (K-S). Pengujian dilakukan pada signifikansi 0,05 atau $5 \%$ sehingga kriteria dinyatakan normal apabila nilai K-S Z memiliki sig>0,05 dengan kata lain $\mathrm{H}_{\mathrm{o}}$ jika data berdistribusi normal, dan $\mathrm{H}_{\mathrm{a}}$ jika data tidak berdistribusi secara normal (Ghozali, 2011, p. 34).

Tabel 1. Hasil Analisis Deskriptif Motivasi Belajar Kelas Eksperimen dan Kelas Kontrol

\begin{tabular}{lcccccc}
\hline \multirow{2}{*}{ Ket. } & \multicolumn{3}{c}{ Pretest } & \multicolumn{3}{c}{ Posttest } \\
\cline { 2 - 7 } & KE1 & KE2 & KK & KE1 & KE2 & KK \\
\hline Mean & 51,03 & 50,30 & 49,82 & 68,34 & 70,30 & 59,61 \\
Median & 51 & 48 & 51 & 68 & 70 & 59 \\
Standar Deviasi & 3,98 & 7,63 & 4,46 & 2,40 & 2,27 & 3,05 \\
Varians & 15,89 & 58,22 & 19,86 & 5,80 & 5,14 & 9,28 \\
Skor Minimum & 43 & 40 & 38 & 63 & 66 & 55 \\
Skor Maksimum & 61 & 69 & 55 & 73 & 75 & 68 \\
Banyak Peserta Didik & 29 & 27 & 28 & 29 & 27 & 28 \\
\hline
\end{tabular}

Tabel 2. Hasil Analisis Deskriptif Hasil Belajar Kognitif Kelas Eksperimen dan Kelas Kontrol

\begin{tabular}{lcccccc}
\hline & \multirow{3}{*}{ Ket. } & Pretest & \multicolumn{3}{c}{ Posttest } \\
\cline { 2 - 7 } & KE 1 & KE 2 & KK & KE 1 & KE 2 & KK \\
\hline Mean & 13,28 & 13,37 & 12,57 & 22,00 & 21,70 & 18,25 \\
Median & 12 & 13 & 12,5 & 22 & 22 & 18 \\
Standar Deviasi & 3,02 & 3,14 & 2,18 & 1,22 & 1,44 & 1,32 \\
Varians & 9,14 & 9,86 & 4,77 & 1,50 & 2,06 & 1,75 \\
Skor Minimum & 9 & 8 & 9 & 19 & 18 & 16 \\
Skor Maksimum & 20 & 21 & 18 & 24 & 24 & 21 \\
\hline Banyak Peserta Didik & 29 & 27 & 28 & 29 & 27 & 28 \\
\hline
\end{tabular}

Keterangan:

KE1 : kelas eksperimen 1 
Jurnal Prima Edukasia, 5 (1), January 2017 - 17

Corry Febriani

KE 2 : Kelas eksperimen 2

KK : Kelas Kontrol

Tabel 3. Hasil Uji Normalitas

\begin{tabular}{cccc}
\hline \multirow{2}{*}{ Variabel } & \multicolumn{3}{c}{ Signifikansi Kolmogrov-Smirnov } \\
\cline { 2 - 4 } & $\begin{array}{c}\text { Kelompok } \\
\text { Eksperimen 1 }\end{array}$ & $\begin{array}{c}\text { Kelompok } \\
\text { Eksperimen 2 }\end{array}$ & $\begin{array}{c}\text { Kelompok } \\
\text { Kontrol }\end{array}$ \\
\hline Pretest Motivasi Belajar & 0,711 & 0,752 & 0,708 \\
Posttest Motivasi Belajar & 0,908 & 0,7943 & 0,847 \\
Pretest Hasil Belajar Kognitif & 0,706 & 0,918 & 0,992 \\
Posttest Hasil Belajar Kognitif & 1,207 & 1,234 & 0,999 \\
\hline
\end{tabular}

Tabel 4. Uji Homogeniatas Univariat Levene Test

\begin{tabular}{clcccc}
\hline Tahap & \multicolumn{1}{c}{ Variabel Terikat } & F & df1 & df2 & Sig. \\
\hline Pretest (Awal) & Pretest Motivasi & 2,402 & 2 & 81 & 0,097 \\
& Pretest Hasil Belajar Kognitif & 1,564 & 2 & 81 & 0,215 \\
Posttest (Akhir) & Post Motivasi & 0,323 & 2 & 81 & 0,725 \\
& Posttest Hasil Belajar Kognitif & 0,404 & 2 & 81 & 0,669 \\
\hline
\end{tabular}

Berdasarkan hasil uji normalitas menunjukkan bahwa data pretest dan posttest motivasi belajar maupun hasil belajar kongitif peserta didik pada kelas eksperimen 1, eksperimen 2 dan kontrol mempunyai nilai signifikansi yang lebih besar dari nilai alpha yang ditetapkan yaitu $5 \%(0,05)$, yang berarti Ho diterima dan $\mathrm{H}_{1}$ ditolak. Berdasarkan hasil perbandingan nilai signifikansi dengan nilai alpha tersebut dapat disimpulkan bahwa data pretest dan posttest motivasi belajar dan hasil belajar kognitif pada kelas eksperimen 1, eksperimen 2 dan kontrol berdistribusi normal.

\section{Uji Homogenitas}

Uji homogenitas yang dipakai dalam penelitian ini adalah Pengujian homoenitas univariate dilakukan dengan menggunanakn Levene Test, sedangkan untuk multivariat dilakukan dengan menggunakan Box's $M$.

Tabel 4 menunjukkan bahwa nilai signifikansi hasil Levene Test memiliki signifikansi besar dari 0,05 sehingga dapat disimpulkan bahwa seluruh subjek penelitian telah homogen.

Tabel 5. Uji Homogenitas Multivariat Box's M.

\begin{tabular}{ccc}
\hline Statistik & Pretest (Awal) & Posttest (Akhir) \\
\hline Box's M & 3,904 & 12,059 \\
F & 0,627 & 1,938 \\
df1 & 6 & 6 \\
df2 & 159765,771 & 159765,771 \\
Sig. & 0,709 & 0,071 \\
\hline
\end{tabular}

Tabel 5 menunjukkan bahwa nilai signifikannya $<0,025$, hal ini berarti Ho ditolak H1 diterima. Dari hasil ini dapat disimpulkan bahwa terdapat perbedaan pengaruh antara media video dikelas eksperimen dan media gambar dikelas kontrol terhadap motivasi belajar peserta didik dan hasil belajar kognitif secara terpisah. Media video lebih memberikan pengaruh positif dan signifikan terhadap motivasi belajar dan hasil belajar kognitif peserta didik secara terpisah pada peserta didik kelas $\mathrm{V}$ SD Se gugus 04 Palangka Raya.

Hasil Uji Hipotesis

Pengujian prasyarat analisis menunjukkan bahwa distribusi data yang diperoleh telah normal dan homogen kemudian dilanjutkan pada pengujian hipotesis yang terdiri atas:

\section{Uji Univariat}

Pengujian univariat ini digunakan untuk menguji media video terhadap motivasi belajar dan hasil belajar kognitif secara terpisah menggunakan independent sample t-test yang dilakukan pada hasil posttest kelas eksperimen I, II dan kelas kontrol.

Kriteria keputusannya dengan $\alpha=0,025$. Ho ditolak jika $\mathrm{t}$ hitung $>\mathrm{t}$ tabel atau nilai signifikansinya $<0,025$. Berikut adalah tabel ringkasan analisis independent sample $t$ test hasil posttest kelas eksperimen dan kelas kontrol. 
Jurnal Prima Edukasia, 5 (1), January 2017 - 18

Corry Febriani

Tabel 6. Hasil Uji dengan independent sample T-test Postest Kelas Eksperimen dan Kelas Kontrol.

\begin{tabular}{rlllll}
\hline Kelas & \multicolumn{1}{c}{ Variabel } & t $_{\text {hitung }}$ & Df & Sig & Keterangan \\
\hline KE 1 \& KK & MB & 12,789 & 55 & 0,000 & Ada perbedaan \\
& HBK & 11,111 & 53 & 0,000 & Ada perbedaan \\
KE 2 \& KK & MB & 14,717 & 55 & 0,000 & Ada perbedaan \\
& HBK & 9,281 & 53 & 0,000 & Ada perbedaan \\
\hline
\end{tabular}

\section{Uji Multivariat}

Analisis untuk uji beda multivariat dilakukan dengan menggunakan Manova yang dihitung dengan bantuan SPSS 16,0 for windows. Pengujian ini dilakukan untuk mengetahui apakah media video memberikan pengaruh yang positif dan signifikan terhadap motivasi belajar dan hasil belajar kognitif pesertta didik secara bersama-sama. Perhitungan dilakukan dengan rumus Hotteling's Trace dimana hasilnya dapat dilihat pada Tabel 7.

Tabel 7. Hasil Penghitungan dengan Hotteling's Trace Manova

\begin{tabular}{lccccc}
\hline Test & Value & F & Df & Error df & Sig \\
\hline Pre & 0,017 & 0,332 & 4,000 & 158,000 & 0,856 \\
Post & 4,415 & 87,197 & 4,000 & 158,000 & 0,000 \\
\hline
\end{tabular}

Tabel 7 menunjukkan bahwa nilai signifikansi untuk pretest menunjukkan $0,856>0,05$ berarti tidak terdapat perbedaan kesimpulannya adalah anatar kelas eksperimen dan kelas kontrol tidak menunjukkan adanya perbedaan. Sedangkan untuk posttest nilai signifikansi yang diperoleh adalah $0,000<0,05$ berarti terdapat perbedaan kesimpulannya terdapat perbedaan rata-rata kemampuan akhir kelas kontrol dan kelas eksperimen. Dari hasil perhitungan tersebut menunjukkan bahwa terdapat perbedaan antara kelas eksperimen dan kelas kontrol sehingga dapat disimpulkan bahawa media video memberikan pengaruh yang signifikan terhadap motivasi belajar dan hasil belajar kognitif peserta didik kelas V SD Se gugus 04 Palangka Raya.

Pembahasan

Keseluruhan hasil penelitian membuktikan bahwa media video ini memberikan pengaruh yang positif dan signifikan terhadap motivasi belajar dan hasil belajar kognitif pada mata pelajaran IPA kelas V SD se-gugus 04 Palangka Raya. Hal ini sejalan dengan penelitian yang dilakukan oleh Housand dan Housand (2012, p. 706) yang mengatakan bahwa dengan adanya teknologi berupa media video dapat meningkatkan motivasi.media video merupan teknologi yang dapat membuat peserta didik termotivasi dalam belajar. Hal ini juga dipertegas oleh Odera (2011, p. 283) mengatakan bahwa penggunaan media pendidikan dan teknologi dianggap dapat memberikan motivasi kepada siswa selama proses pembelajaran berlangsung. Media memiliki pengaruh besar pada saat proses pembelajaran berlangsung. Hal yang sama juga di ungkapkan oleh Star, Chen, Taylor, Durkin, Dede dan Chao (2014, p. 2) bahwa salah satu cara untuk memicu motivasi, minat dan membangun rasa kompetensi dalam pembelajaran matematika dan sains adalah melalui penggunaan berbagai media teknologi berupa media video. Melalui media video yang diberikan pada pembelajaran IPA dapat memicu motivasi peserta didik sehingga dapat membangun rasa kompetensi bagi peserta didik.

Pembelajaran IPA merupakan salah satu mata pelajaran yang berperan penting dalam mewujudkan generai penerus bangsa yang cerdas dalam berpendidikan wawasan, keterampilan dan sikap ilmiah sejak dini. Oleh karena itu pembelajaran IPA wajib ditempuh oleh peserta didik di sekolah dasar. Dalam perkembangannya, pembelajaran IPA dapat menjadi wahana bagi peserta didik untuk mempelajari diri sendiri dan sekitarnya, serta bertujuan untuk menembangkan pengetahuan dan pemahaman konsep-konsep IPA yang bermanfaat dan dapat diterapkan dalam kehidupan seharihari (BSNP, 2006, p. 162). Melalui pembelajaran IPA ini peserta didik mampu menerapkan ilmu yang diperoleh dalam kehidupan sehariharinya. Berhubungan dengan pembelajaran IPA yang diajarkan pada sekolah dasar maka pembelajaran IPA tersebut harus disajikan dengan bantuan media pembelajaran agar pembelajaran tersebut dapat membuat peserta didik tertarik pada saat proses pembelajaran. Hal ini disebabkan oleh karakteristik usia peserta didik kelas V SD yang masih bersifat operasional konkret sehingga mengakibatkan guru untuk lebih aktif dan kreatif menjelaskan pembelajaran agar peserta didik tidak bosan pada saat kegiatan belajar mengajar berlangsung.

Pemanfaatan media pembelajaran dalam belajar IPA dapat menjadi perantara yang tepat dalam menyampaikan informasi penting pada 


\section{Jurnal Prima Edukasia, 5 (1), January 2017 - 19}

Corry Febriani

saat proses pembelajaran. Pada kesempatan ini akan diabahas tentang penggunaan media pembelajaran berupa media video hubungannya dengan motivasi belajar dan hasil belajar kognitif pada peserta didik kelas $\mathrm{V}$ sekolah dasar. Media video dipilih karena mampu menjelaskan hal-hal yang abstrak menjadi kelihatan nyata, media video ini sangat cocok untuk mejelaskan pembelajaran IPA dengan materi peristiwa alam karena meelalui video ini peserta didik dapat melihat peristiwa alam yang sebelumnya tidak pernah mereka lihat. Penggunaan media video ini dapat menjadi alternatif sekaligus inovasi guru dalam membelajarkan materi yang bersifat abstrak maupun yang berbahaya. Media video sangat menarik perhatian peserta didik karena dapat memberikan motivasi, mengembangkan imajinasi, memperjelas hal-hal yang abstrak menjadi lebih relistik dan dapat mengatasi keterbatasanjarak dan waktum (Munandi, 2013, p. 127). Melalui media video ini peserta didik dapat berimajinasi bagaimana jika mereka sedang berada diperistiwa alam yang terdapat pada video tersebut, sehinggga peserta didik dapat mengembangkan pemikiran mereka dapat mengetahui cara jika suatu saat mengalami kejadian tersebut dan cara mengatasi agar peristiwa alam tersebut tidak terjadi misalnya saja pada peristiwa banjir. Media video sangat baik dalam menarik perhatian dan minat peserta didik untuk belajar, karena melalui media video dapat meberikan efek animasi sehingga dapat mengundang ketertarikan peserta didik dalam belajar. Sebagaimana dinyatakan oleh Sebagaimana yang dinyatakan oleh Greenberg dan Zanefis (2012, p. 5) video menggabungkan berbagai jenis data (gambar, gerak, suara, teks) secara komplementer, belajar dapat disesuaikan lebih mudah dibandingkan dengan alat-alat lain untuk gaya belajar yang beragam dan kecepatan belajar individu siswa. Melalui gambar, gerak suara dan teks ini lah dapat membantu peserta didik dalam memamhami materi pembelajaran yang diberikan oleh guru sehingga peserta didik mampu memahami pembelajaran dengan mudah dan cepat.

Perhitungan tersebut didukung juga dengan hasil pengamatan empiris yang dilakukan pada setiap pertemuan dalam proses pembelajaran. Kelas yang menggunakan media video pada proses pembelajaran IPA terlihat begitu aktif, bersemangat dan termotivasi saat proses pembelajaran karena dengan media video dapat menghasilkan animasi, gerak dan suara yang dapat menarik ketertarikan peserta didik dalam belajar. Hal ini diperkuat oleh penelitian yang dilakukan oleh Edna, Beatriz, Pep, Enache dan Fernandez. (2008, p. 2) penggunaan video memiliki efek positif pada presepsi siswa tentang peningkatan motivasi belajar mereka dan mendorong mereka untuk meningkatkan hasil belajar mereka, sehingga siswa dapat menemukan pengetahuan dan mengerti tentang konstruk atau bangunan pengetahuannya sendiri. Penggunaan media video pada saat pembelajaran sangat memotivasi peserta didik dalam belajar sehingga dapat juga mempengaruhi hasil belajar peserta didik. Kemudian hal ini juga diperkuat oeleh penelitian yang dilakukan oleh Liswijaya (2012, p. 136) yang mengatakan bahwa media pembelajaran dengan media video pada pembelajaran kimia dapat menigkatkan motivasi dan hasil belaajr peserta didik. Sangat terlihat jelas bahwa penggunaan media video ini dapat meningkatkan motivasi belajar dan hasil belajar peserta didik.

Media video yang digunakan dalam pembelajaran mampu memberikan rangsangan belajar yang lebih baik bagi peserta didik karena dengan media video peserta didik dapat mengingat materi pembelajaran lebih lama. Penelitian Jacobs dan Schade dalam Munir (2012, p. 232) membuktikan hal ini dengan mengungkapkan bahwa daya ingat siswa yang hanya membaca saja memberikan presentase terendah, yaitu, $1 \%$. Daya ingat siswa dapat ditingkatkan hingga 25\%-30\% dengan bantuan medi lain seperti televisi. Daya ingat siswa makin meningkat hingga $60 \%$ dengan penggunaan multimedia. Media video hampir sama dengan multimedia karena dapat menampilkan gambar, teks, suara dan animasi dalam sebuah tampilan yang menarik.

Pembelajaran dengan menggunakan media video untuk mengatasi kendala atau kesulitan yang terjadi dalam proses pembelajaran IPA. Proses pembelajaran yang baik akan mendukung keberhasilan dalam suatu kegiatan pembelajaran. Atas dasar inilah peneliti melakukan suatu eksperimen dengan menggunakan media video dalam pembelajaran IPA yang belum pernah dilaksanakan sebelumnya. Pembelajaran dengan menggunakan media video ini bertujuan untuk mengatasi persoalan dalam pembelajaran IPA di SD Segugus 04 Palangka Raya yang cenderung monoton karena pembelajaran yang diberikan oleh guru dinilai kurang membuat peserta didik aktif dan kreatif. Media video selain dapat memotivasi peserta didik dalam belajar juga mampu mengoptimalkan 


\section{Jurnal Prima Edukasia, 5 (1), January 2017 - 20 \\ Corry Febriani}

hasil belajar kognitif IPA peserta didik. Hal ini sesuai dengan penelitian yang dilakukan oleh Adedapo, Salawu, dan Afolabi. (2010, p. 1) mengatakan bahwa media video digunakan untuk mendukung dan merangsang pembelajaran dikelas, perkembangan kognitif dan pembangunan moral. Agar perkembangan kognitif dapat berkembangan dengan baik maka pada saat poses pembelajaran dapat dirangsang melalui penggunaan media video. Hal senada juga terdapat pada penelitian yang dilakukan oleh Hee Jun Choi dan Minwha Yang (2011, p. 551) yang mengatakan bahwa video dapat menjadi media efektif yang menyajikan situasi otentik untuk meningkatkan kepuasan siswa, empati dan prestasi belajar siswa. Media video merupakan media yang efektif dalam menyajikan situasi yang otentik.

Bertitik tolak pada hasil penelitian dan pemaparan di atas, maka dapat disimpulkan bahwa penggunaan media video lebih berpengaruh positif dan signifikan terhadap motivasi belajar dan hasil belajar kognitif pada pembelajaran IPA. Dengan penggunaan media video di kelas dapat membuat pembelajaran lebih bermakna sehingga dapat menumbuhkan motivasi belajar dan mengoptimalkan hasil belajar kognitif IPA di kelas V SD Se Gugus 04 Palangka Raya.

\section{Simpulan}

Penelitian ini membuktikan bahwa terdapat pengaruh positif pada pembelajaran IPA yang menggunakan media video dibandingkan dengan pembelajaran IPA yang menggunakan media gambar terhadap motivasi belajar dan hasil belajar kognitif pembelajaran IPA. Media video yang diberikan guru pada proses pembelajaran IPA membuat motivasi belajar dan hasil belajar kognitif peserta didik meningkat hal ini dikarenakan peserta didik menjadi lebih bersemangat dan bergairah dalam belajar karena adanya inovasi baru yang diberikan guru pada saat pembelajaran.

\section{Daftar Pustaka}

Adedapo, Y. A., Salawu, I. O., \& Afolabi, A. O. (2010). Effects of video and audio taped instruction on cognitive learning outcomes in economics. Ilorin Journal of Education, 1-8. Diakses pada tanggal 25 Oktober 2015 pukul 16.30 WIB, dari http://www.aessweb.com.org/index.php? $\mathrm{ht}=$ action/GetDocumentAction/i/13334.
BNSP. (2006). Standar Isi. Jakarta: BNSP.

Brophy, J. (2010). Motivating students to learn third edition. London: Routledge.

Buxton, C. A. \& Provenzo, E. F, Jr. (2007). Teaching science in elementary \& middle school, a cognitive and cultural approach. London: Sage Publications, Inc.

Edna, B., Beatriz, A., Pep, S., Enache, M \& Fernandez, V. (2008). Video as a new teaching tool to increase studentmotivation. Technical University of Catalonia Barcelona, Spain. Diakses pada tanggal 4 September 2015, dari

Greenberg, A. D., \& Zanefis, J. (2012). The impact of broadcast and streaming video in education. London: Report commissioned by Cisco Systems.

Ghozali, I. (2011). Aplikasi multivatiate dengan program ibm spss 19. Semarang: Badan Penerbit Universitas Diponegoro.

Hee Jun Choi \& Minwha Yang. (2011). The effect of problem-based video instruction on student satisfaction, empathy, and learning achievement in the Korean teacher education context. Springer Science+Business Media, 62, 551-561. Diakses pada tanggal 2 November 2015, dari dari http://www.vdac.de/vdac/index.php?opti on=com docman \&task $=$ doc view $\&$ gid $=$ $\underline{149}$.

Housand, B. C., \& Housand, A. M. (2012). The role of technology in gifted students' motivation. Psychology in the Schools, 49(7). Diakses pada tanggal 12 Oktober 2015, dari http://eresources.pnri.go.id:2057/docview/15090 47421? pq-origsite $=$ summon.

Indaryati, \& Jailani. (2015). Pengembangan media komik pembelajaran matematika meningkatkan motivasi dan prestasi belajar siswa kelas V. Jurnal Prima Edukasia, 3, 84-96.

Jamaris. (2013). Orientasi baru dalam psikologi pendidikan. Bogor: Ghalia Indonesia. 


\section{Jurnal Prima Edukasia, 5 (1), January 2017 - 21 \\ Corry Febriani}

Jihad, A \& Haris, A. (2008). Evaluasi pembelajaran. Yogyakarta: Multi Pressindo.

Kustandi, C \& Sutjipto, B. (2013). Media pembelajaran. Bogor: Ghalia Indonesia.

Liswijaya. (2012). Pengembangan media pembelajaran kimia berbantuan komputer pada materi reaksi reduksi oksidasi untuk meningkatkan motivasi dan hasil belajar peserta didik kelas $X$. Tesis magister, tidak diterbitkan. Universitas Negeri Yogyakarta.

Manning, S \& Johson, K. E. (2011). The technology toolbelt for teaching. San Fransisco. Published by Jossey-Bass.

Michael, O., McClendon, V., \& Branch, M. (2009). Educational media and technology yearbook. London: Springer.

Muijs, D \& Reynolds, D. (2008). Effective teaching, teori dan aplikasi. (Terjemahan Helly Prajitno Soetjipto \& Sri Mulyantini Soetjipto). London: Sage Publication. (Buku asli diterbitkan 2008).

Munandi, Y. (2013). Media pembelajaran, sebuah pendekatan baru. Jakarta: Referensi GP Press Group.

Munir. (2012). Multimedia konsep dan aplikasi dalam pendidikan. Bandung: Alfabeta.

Odera, F. Y. (2011). Motivation: the most ignored factor in classroom instruction in kenyan secondary school. International Journal of Science and Technology, 1, 283-288. Diakses pada tanggal 3 November 2015, dari http://eresources.pnri.go.id:2075/media/p q/classic/doc/1798979291/fmt/pi/rep/NO $\mathrm{NE}$ ?hl=\&cit\% .

Rusman. (2013). Belajar dan pembelajaran berbasis komputer: mengembangkan profesionalisme guru abad 21. Jakarta: Alfabeta, cv.

Schunk, D. H., Pintrich, P. R., \& Meece, J. L. (2010). Motivation in education: theory, research, and applications $\left(3^{\text {rd }}\right.$ ed.). Columbus: Pearson Education.

Star, J. R., Chen, A. J., Taylor, M. W., Durkin, K., Dede, C \& Chao, T. (2014). Studying technology-based strategies for enhancing motivation in mathematics. International Journal of STEM Education, 1-7. Diakses pada tanggal 10 Oktober 2015, dari http://web.a.ebscohost.com/ehost/pdfvie wer/pdfviewer?sid=7f32fb47-b37e-410d$\underline{\mathrm{a} 9 \mathrm{c} 4}$ ce9583b34c84\%40sessionmgr4004\&vi= $1 \&$ hid=4206.

Yamin, M. \& Maisah. (2009). Manajemen pembelajaran kelas. Jakarta : Gaung Persada. 